TITLE:

\title{
LARVAL DEVELOPMENT OF A SPIONID POLYCHAETE PARAPRIONOSPIO PINNATA (EHLERS)
}

$\operatorname{AUTHOR}(S)$ :

Yokoyama, Hisashi

CITATION:

Yokoyama, Hisashi. LARVAL DEVELOPMENT OF A SPIONID POLYCHAETE

PARAPRIONOSPIO PINNATA (EHLERS). PUBLICATIONS OF THE SETO MARINE BIOLOGICAL LABORATORY 1981, 26(1-3): 157-170

ISSUE DATE:

1981-03-30

URL:

http://hdl.handle.net/2433/176017

RIGHT: 


\title{
LARVAL DEVELOPMENT OF A SPIONID POLYGHAETE PARAPRIONOSPIO PINNATA (EHLERS)
}

\author{
HTSASHI YOKOYAMA \\ Department of Fisheries, Kyoto University
}

With Text-Figures $1-8$ and Table 1

\begin{abstract}
Data concerning the development of the spionid polychaete Paraprionospio pinnata are derived from specimens which were obtained from the plankton in Kumihama Bay and reared in the laboratory. Descriptions and figures are given on the pelagic larva from 2- to 38-segment stage and the metamorphosed juvenile. The red pigments on the lateral lips and the absence of larval setae in segment 2 are diagnostic features of the larval stage in this species. The characteristics similar to those for the adult (e.g. branchiae, palpi, parapodial lamellae and hooded hooks) appear successively as the larva grows. Metamorphosis occurred at 33- to 37-segment stage in the laboratory culture, of which sizes of the specimens were rather smaller than those of the specimens obtained from the bottom of the sea. Among the spionid larvae listed from the literatures, Parapronospio pinnata is largest in size and in the number of segments at metamorphosis.
\end{abstract}

\section{Introduction}

The spionid polychaete Paraprionospio pinnata (Ehlers) is commonly found in Japanese waters and appears as a dominant species in the area where organic matter is abundant and oxygen content is frequently reduced in summer, such as Tokyo Bay (Horikoshi and Imajima, 1976), Ise Bay (Miyadi, 1941), Osaka Bay (Joh et al., 1969) and Naka-Umi (Kikuchi, 1964). This species is included among pollution indicator organisms (Kitamori, 1969; Kikuchi, 1978). However, many aspects of its life cycle and biology have been overlooked and little information is available regarding the larval development of this species.

Berkeley and Berkeley (1961) described and figured some larvae found off the coast of Peru as a new species, Prionospio ornata. They also reported the neotenous larvae of Paraprionospio pinnata from the same locality, and distinguished them from Prionospio ornata larvae by the presence of large membranous lateral wings which infold the prostomium (Berkeley and Berkeley, 1963, 1964). Foster (1971) examined the materials described by Berkeley and Berkeley (1961), rewrote the figures, and made some remarks on Paraprionospio pinnata larva. He pointed out that Prionospio ornata possessed the peristomial wings and several other characteristics (e.g. a conspicuous sheath of palpi, a dorsal ridge in setiger 1 and sabre-setae) which were in common with the specimens identified as Paraprionospio pinnata by the Berkeleys (1963). Therefore, he considered that the two species were synonymous, excluding the specimen presented in 1964 due to its possession of a single spine on

Publ. Seto Mar. Biol. Lab., XXVI (1/3), 157-170, 1981.

(Article 8) 
setiger 10 and the succeeding setigers. However, the diagnoses and figures they gave are restricted to a single stage of development, which was estimated as just before the settlement. Moreover, as stated later, there are some doubts in identity of the specimens examined by them with Paraprionospio pinnata.

While examining the plankton samples collected from Kumihama Bay, Kyoto Prefecture, I noticed that several species of spionid larvae were present in the samples. As to the larvae in the early stages of development, it was almost impossible to distinguish them into different species, because of a close resemblance between them. However, the larvae of the 2-segment stage and the succeeding stages could be separated by species, for they exhibit diagnostic characters of respective species throughout all subsequent stages.

In this paper, descriptions and figures are given on the pelagic larvae and the metamorphosed juvenile, which were identified to belong to Paraprionospio pinnata by the possession of specific characters.

\section{Materials and Methods}

Since ripe adults were not available for laboratory fertilization, the development of Paraprionospio pinnata was followed with the specimens obtained from the plankton. Larvae were collected from Kumihama Bay, where the large population of the adult Paraprionospio pinnata* inhabited the mud bottom (Hayashi et al., 1977). Plankton tows were taken vertically from a depth of $15 \mathrm{~m}$ to the surface monthly from 1977 to 1979 by a XX13 (95 $\mu$ mesh) plankton net. Larvae were separated from the plankton samples and reared in the laboratory through metamorphosis. In order to compare the metamorphosed specimens with the juveniles settled on the bottom of the sea, bottom samples were obtained from Kumihama Bay in September, 1979 by an Ekman-Birge grab. Grab samples were washed over a $0.25 \mathrm{~mm}$ sieve to collect juveniles. Observations and measurements were made on living specimens after relaxation with $\mathrm{MgCl}_{2}$. The treatment with $\mathrm{MgCl}_{2}$ did not bring on a noticeable change in the natural size of the specimen.

\section{Observations}

The 2-segment stage larva (Fig. 1, A-B)

An earlist recognizable larva measures $281 \mu$ in length at the 2-segment stage.

\footnotetext{
* Recently I noticed that this species comprises distinct forms of morphological variations. Among the specimens obtained from Kumihama Bay, however, noticeable variations were not found. Diagnostic characters of the form from Kumihama Bay are as follows: small papilla on each posterior margin of peristomial wing enfolding prostomium; no pigment spots on lateral sides of peristomium; lamellar plate of branchiae bifoliate, not flabellate; no accessory triangular lamellae on inferior part of 1st branchia; thread-like filament on each base of 3rd branchia; transvers dorsal crests on setigers 21-35, accompanied by hyaline dorsal cuticle; no interramal pouches; no bilobed ridge on ventrum of setiger 8; alternating capillaries on neuropodia of setiger 9 short and bilimbate.
} 
The larva has a round prostomium bearing three eyes. The eyes have dark reddishbrown pigment spots. The medial eye, which is one of an inner pair at later stages, is comparatively small and faint. The prostomium is provided with several pairs of tactile cilia. On the postero-lateral side of the prostomium there are anlagen of nuchal organs bearing weak cilia. The first segment is prominent due to its large setal sac. Larval setae in segment 1 are long and extend beyond a pygidium. In segment 2 they are rather short. The mouth is surrounded by oral cilia. Anlagen of lateral lips are recognized on both sides of the mouth opening. On the outside

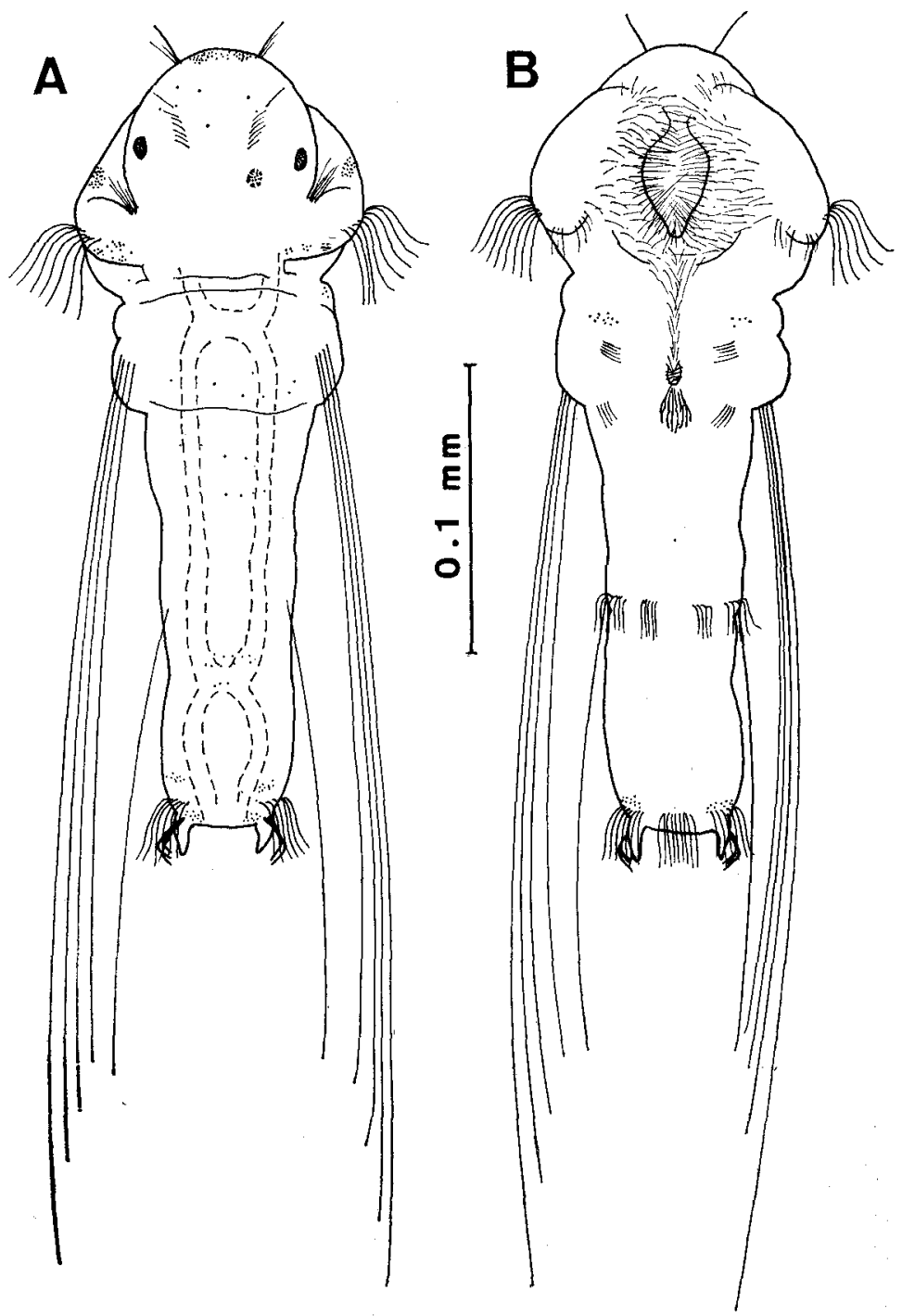

Fig. 1. Larva with 2 segments: A, Dorsal view; B, Ventral vịew. Digestivẹ apparatus is indicated by broken line, 
of the lateral lips there is a pair of red pigmented areas, which are characteristic to this species in every subsequent larval stage. A neurotroch runs posteriorly from the mouth and ends in a small ciliated pit which is located in segment 1. Posterior to the ciliated pit there is a region with relatively long cilia. These cilia move slowly and are directed towards the ciliated pit. There are two pairs of ciliated cells on the ventral side in segment 1 . The anterior pair is directed longitudinally, while the posterior is directed diagonally. A gastrotroch is observed in segment 2 . It consists of four ciliated cells which are situated two by two laterally in the segment. A telotroch is composed of five patches of cilia with a dorsal gap. The pygidium has
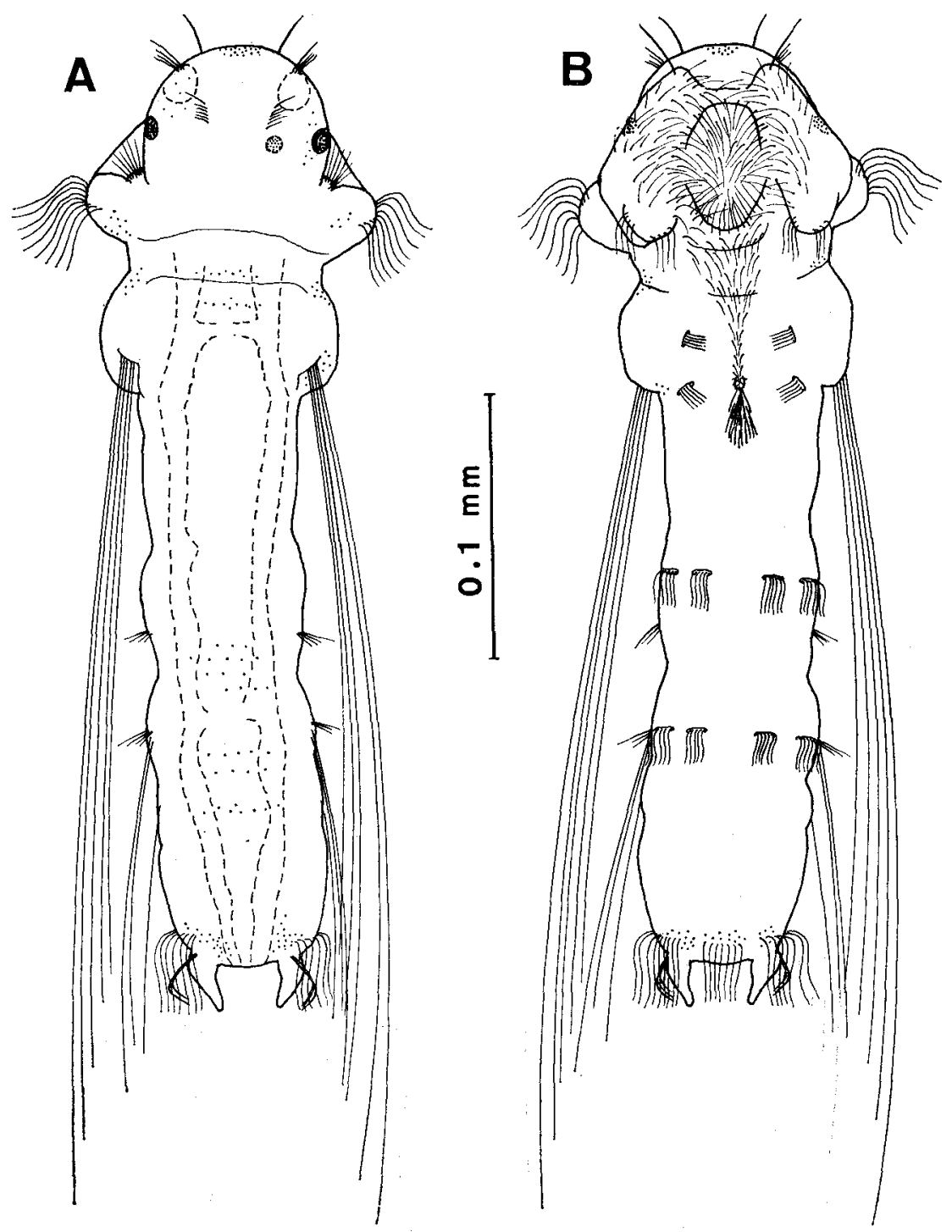

Fig. 2. Larva with 4 segments: A, Dọsal view; B, Ventral vịew, 
two anal cirri. Stiff cilia, which are seen to hold setae, are present dorsally on the base of the anal cirri. Some red pigment patches are present on the anterior margins of the prostomium and on the pygidium. Comparatively smaller red pigment spots are scattered on the prostomium and the dorsum. The digestive apparatus consists of three parts and is densely ciliated inside.

\section{The 4-segment stage larva (Fig. 2, A-B)}

A specimen with four segments measures $362 \mu$ in length. In the antero-lateral part of the prostomium a pair of circular, hyaline areas is found. They are also recognized at the subsequent stages. The lateral lips of the vestibule are developed and the ciliated oral opening is expanded. The inner edges of the lateral lips and the vestibule develop a yellowish-brown pigment. A pair of long tactile cilia rise from the anterior margin of the lateral lips. Long larval setae are not observed in segment 2. The absence of larval setae is also found in the subsequent stages. Weak hairy bristles, which are not of the same type as in the adult, are recognized in segments 2 and 3.

\section{The 7-segment stage larva (Fig. 3, A-B)}

A figured specimen measures $653 \mu$ in length. The body becomes longer and more slender than in the previous stage. Two pairs of eyes are retained. They become dark and appear almost black. In dorsal view inner eyes look round, but when viewed laterally, they appear kidney-shaped. The lateral ones are somewhat larger than the inner pair and look oval or subtriangle in lateral view. In the posterior region of the prostomium a raised ridge appears, extending to the anterior border of segment 1. The lateral lips continue to enlarge. The mouth opens widely by spreading the lateral lips outward. Immediately posterior to the vestibule there is a pair of functionally unknown organs. These organs are round and seem to have a small opening to the cuticle. A small ciliated cell, forming an arc, is situated just behind this organ. On either side of the neurotroch a pair of stiff cilia is found. They perform a slow pendulous movement. The parapodia are well developed except in segment 2, where the long larval setae are not found. Hairy bristles, not of the adult type, are found dorsally and ventrally on all parapodia. Two pairs of bundles of stiff cilia, that serve to hold the larval setae along the dorsal side of the body on swimming, occur dorsally on the pygidium. Behind the pharynx a muscular oesophagus is noticeable in segments 1 to 2 . It has strongly developed walls and has no cilium inside. The characteristic form of this digestive organ is observed not only in the subsequent larval stages but also in the adult specimens.

\section{The larva developing several adult characteristics (Fig. 4, A-B)}

A specimen with 24 segments and a length of $2490 \mu$ is figured for the typical form of this stage. As the larva grows, the prostomium tapers in the anterior end, and the posterior raised ridge of the prostomium becomes more prominent. The nuchal organs become large and oval, Anlagen of palpi appear first in the 17 . 

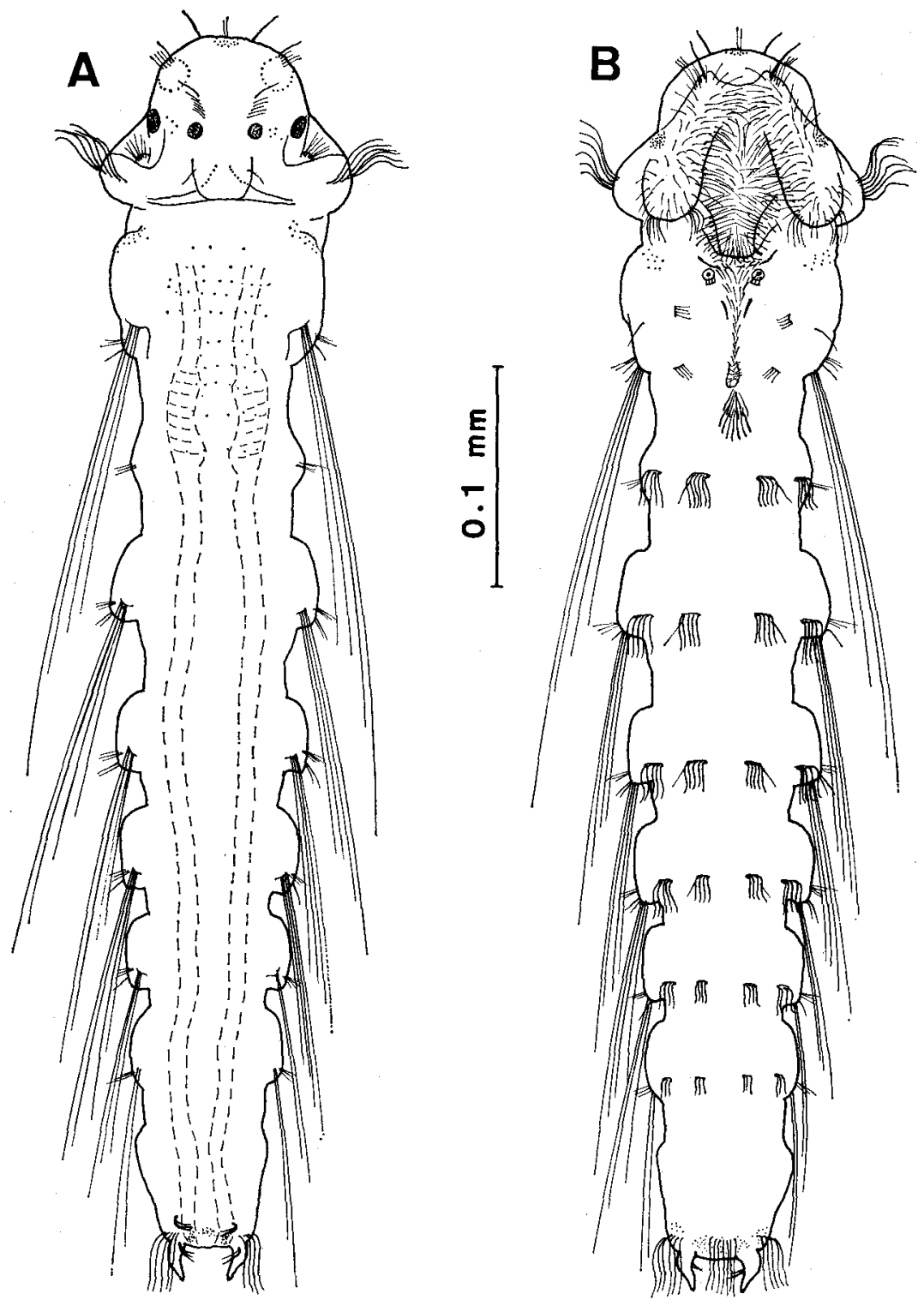

Fig. 3. Larva with 7 segments: A, Dorsal view; B, Ventral view.

segment larva, lateral to the nuchal organs. Branchiae develop first in the 11-segment larva as small protuberances on segment 2. As the larva grows, they become larger and bipinnate, similar to the characteristic form of the adult. A second pair of branchiae become visible first in the 22-segment larva on segment 3 . On the ventral side of segment 1 an additional pair of ciliated cells are formed. They are longitudinally placed. The nototroch is lacking, but nonmotil cilia are thinly found on the dorsum. The same type of cilia are also found on the ventral side. The 

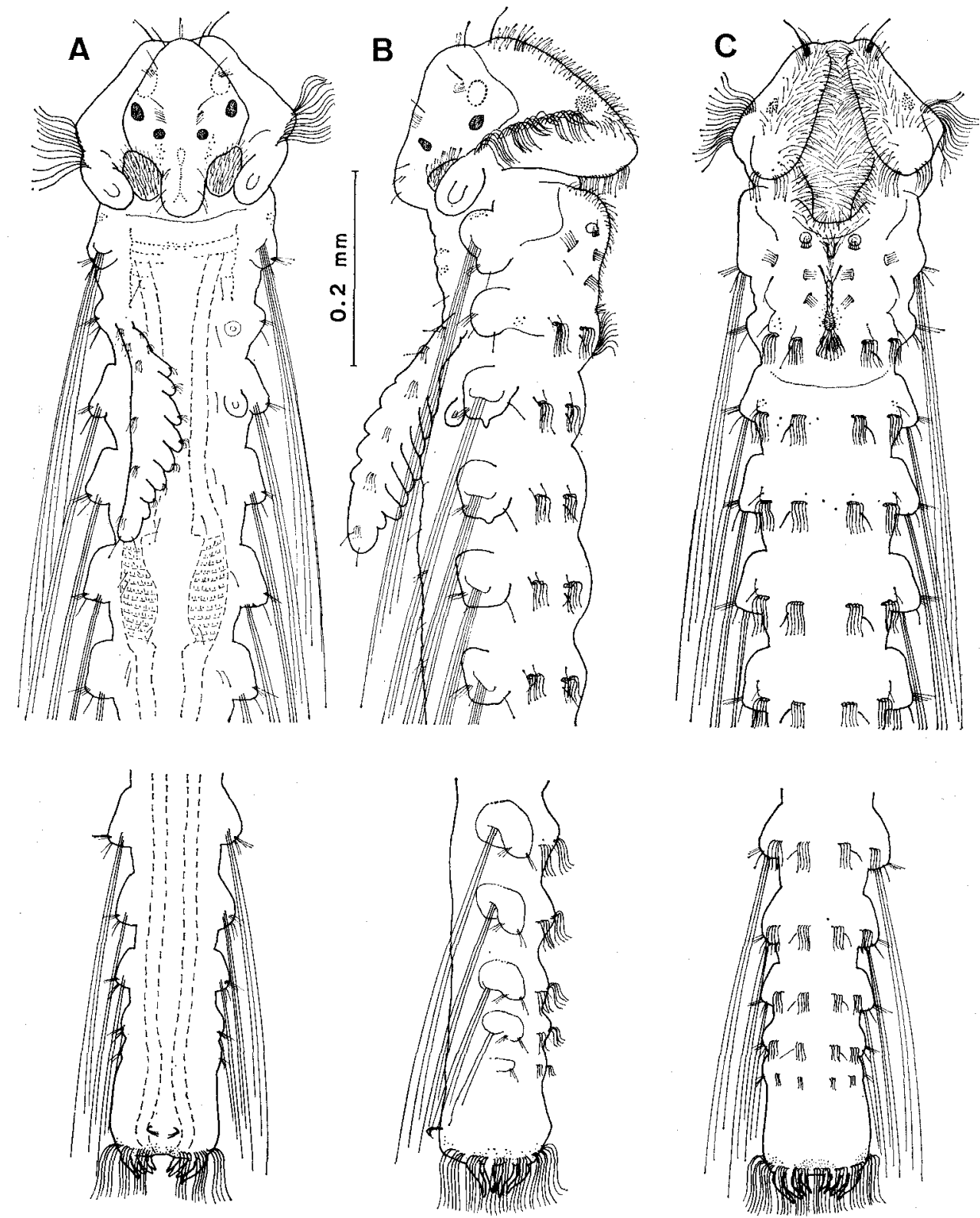

Fig. 4. Larva developing several adult characteristics: A, Dorsal view; B, Lateral view; C, Ventral view. Medial part is omitted.

ciliated cells of the telotroch increase in number to about ten. The anal cirri increase generally, but the number of them varies with individuals from none to ten. The stiff cilia on the anal cirri are shed, but another pair on the pygidium remain. As the segments are added, the muscular oesophagus shifts posteriorly, and in the 24-segment larva it is located in segment 5. 
The larva ready to metamorphose (Fig. 5, A-E)

A specimen which has 35 segments and a length of $4530 \mu$ is figured as the typical form of this stage in which several morphological changes take place. A specimen with 37 segments and a length of $5380 \mu$ is the largest among the larvae examined. The prostomium elongates anteriorly and its shape has a resemblance to the adult. The tactile cilia on the prostomium reduce in number. The tentacular palpi gradually increase in length and bear the characteristics in common with the

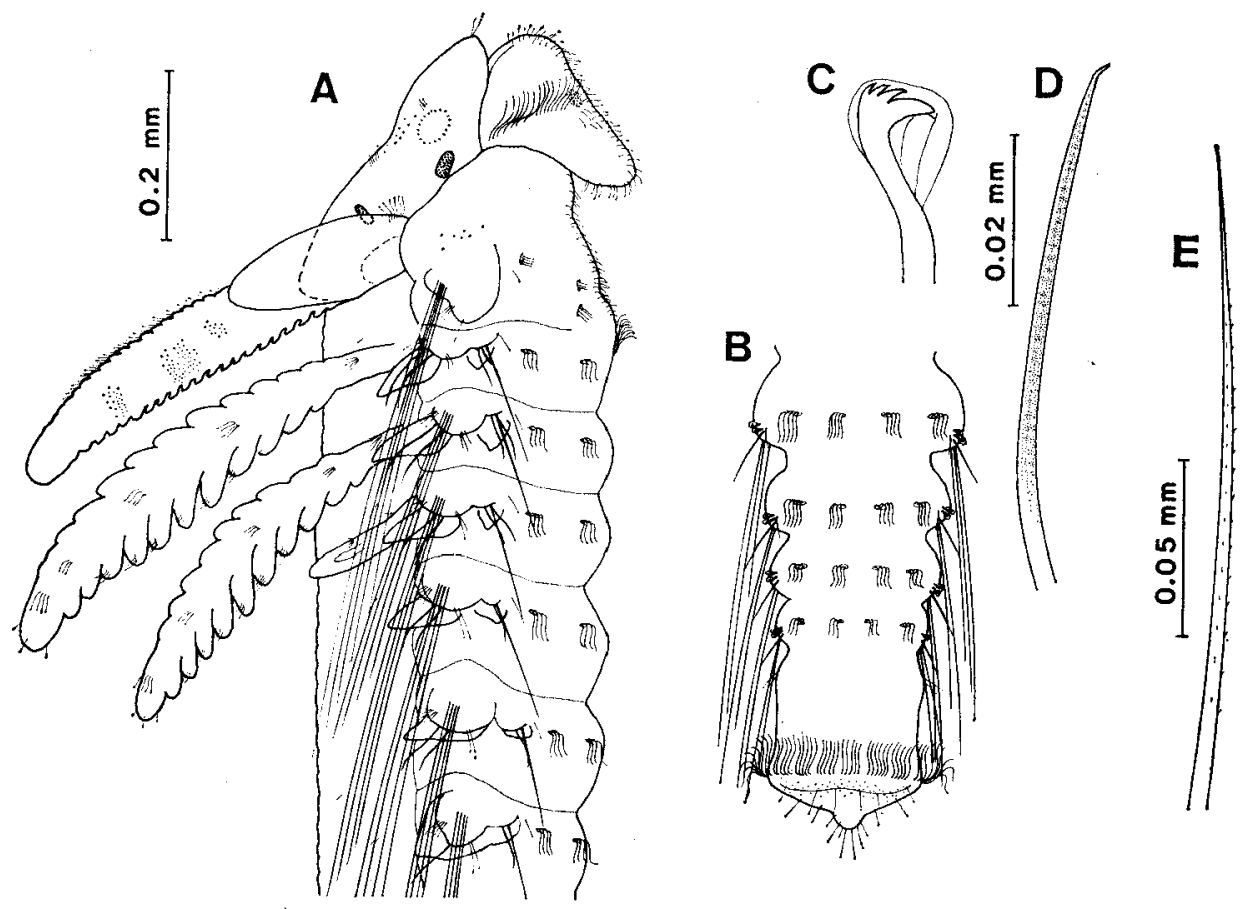

Fig. 5. Larva ready to metamorphose: A, Anterior end in lateral view; B, Posterior end in ventral view; C, Neuropodial hooded hook; D, Sabre-seta; E, Spinous seta from neuropodia.

adult specimen, such as a basal sheath, spotted yellowish-brown pigments and a lacerated, ciliated groove along the inner face. The lateral lips are partially hidden from view, but the prototroch and the red pigment spots on them are still found. The neurotroch, the gastrotroch and the telotroch are as in the previous stage. The anterior two pairs of branchiae are well developed to form the pinnation. The third pair of branchiae are occasionally found on segment 4 in some of the oldest larvae. The shaft and the pinna of the branchia bear many ciliated cells. The notopodial and neuropodial lamellae are differentiated in the anterior segments except in segment 1 . Together with the appearance of parapodial lamellae, capillary setae, which are of the same type as in the adult, are developed in the anterior noto- and neuropodia. The neuropodial hooded hooks appear first in the 27-segment 
larva in segment 10 and the succeeding segments. The hooks have six small teeth in two rows above the main fang. The notopodial hooded hooks are not found in any pelagic larva examined. In some of the oldest larvae, a sabre-seta occurs at the ventral edge of the setal fascicle in segment 10 and the succeeding segments. A single spinous seta, which is not of the same type as the sabre-seta, occurs in some of the neuropodia except in segment 1. This kind of seta is observed only in this stage. The long larval setae and the hairy bristles still remain. Most of the larval anal cirri have fallen off and an anlage of an adult anal cirrus appears mid-dorsally on the pygidium. The margin of the anal cirrus and the anus bears sparse cilia. Pulsating vessels with red blood are observed through the dorsal and ventral cuticles. The muscular oesophagus is located in segments 7 to 8 in the figured specimen. A stomach extends through segment 22 , where it is followed by a straight rectum.

The early benthic stage juvenile (Fig. 6, A-B)

While rearing the larva, several specimens settled on the bottom of the culture vessel. By this time the juveniles were readily recognizable as Paraprionospio pinnata.

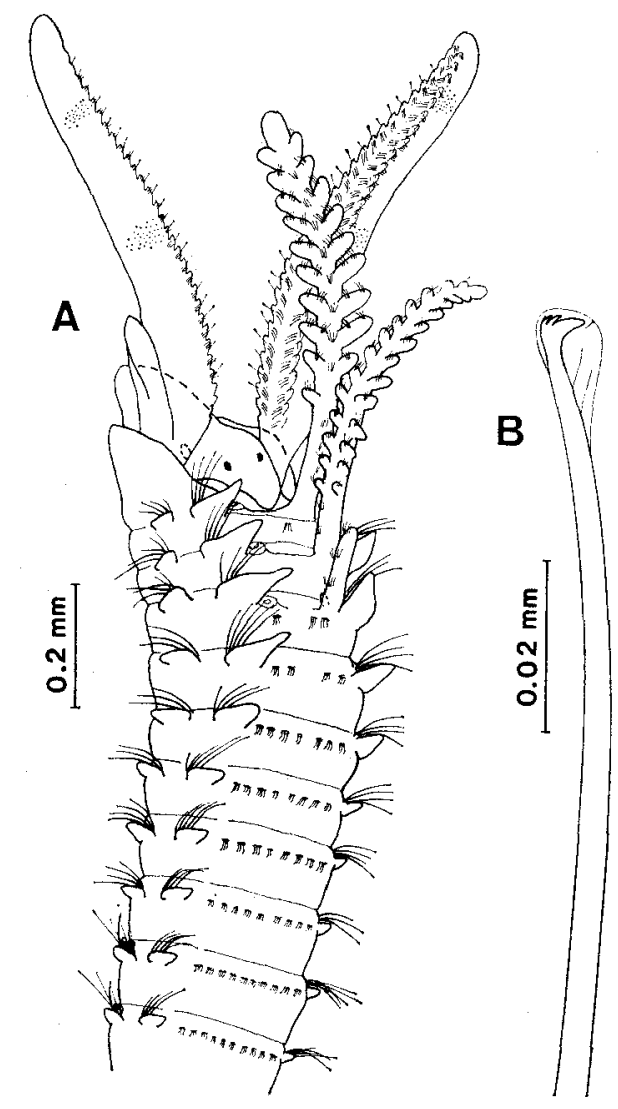

Fig. 6. Early benthic stage juvenile: A, Anterior end in dorso-lateral view; B, Notopodial hooded hook. 
They formed the tubes and were never observed to swim about. Among the metamorphosed specimens a juvenile of 36 segments* (a length of $4090 \mu$ ) is figured. The peristomium grows dorsally, but the peristomial expansions are not so conspicuous as in the adult specimens. The peristomium also extends anteriorly and the lateral lips are almost or completely hidden in the oral cavity together with the prototroch. The neurotroch, the gastrotroch and the telotroch fall off shortly after settlement. The ciliated pit also disappears, as the ciliated cells around this organ fall off. Most kinds of larval cilia are cast off. There is a dorsal ridge connecting the bases of the first pair of branchiae. The branchial pinnation develops well in the anterior two pairs, but the third pair of branchiae is not fully differentiated. Small protuberances, i.e. buds of the thread-like filaments in the adult, are found just in front of the bases of the third branchiae. Transverse ciliated bands are found dorsally on the anterior segments. The first segment has neither parapodial lamellae nor setae and fuses with the peristomium resulting in parapodial loss. In the anterior segments the noto- and neuropodial lamellae are well developed. In the posterior, however, they are not yet differentiated enough. The various kinds of larval setae have already been shed, leaving only the adult setae. Accompanied by neuropodial hooded hooks, the sabre-seta and thin, straight capillaries are found in segment 10 and the succeeding segments. Notopodial slender hooded hooks are present in the segments posterior to segment 31-35. The dorsal crests, which are present in segments 22-36 (setigers 21-35) in the adult specimens, are hardly visible in this stage. On either side of the mid-dorsal anal cirrus two small protuberances of lateral cirri become visible. The red pigments around the anus still remain. The thick muscular oesophagus is found in segments 8 to 9 .

\section{Discussion}

Although the morphological changes through the larval development could not be observed directly, the larvae examined here should belong to one and the same species due to their common characteristics. These characteristics are the red pigments on the lateral lips, the absence of larval setae in segment 2, the arrangement of ciliated cells and so on. Besides these larval characteristics, the adult characteristics (e.g. palpi, branchiae, parapodial lamellae and several types of adult setae) appear successively as the segments are added (Fig. 7). Moreover, the juveniles which settled in the culture vessel were exactly the same as the specimens obtained from the seabed. Therefore, the larva examined here can undoubtedly be refered to Paraprionospio pinnata.

As noted earlier, Foster (1971) re-examined the materials which had been reported from off Peru by Berkeley and Berkeley (1961, 1963, 1964), and confirmed that the specimens other than those presented in 1964 were the larvae of Paraprionospio

\footnotetext{
* In this paper, the number of segments of the juvenile is defined as that including the achactous prebranchial segment and excluding the peristomium.
} 
pinnata. Several characteristics found in the Peru specimens (e.g. the long larval setae in segment 1, the gastrotroch and the telotroch) are also found in the present specimens. However, the larval characteristics found in the present specimens, such as the lateral lips, the prototroch and ciliated pit, are not recorded for the Peru specimens. The Peru specimens bear the peristomial wings, which are formed far after the settlement in the present specimens. Moreover, the Peru specimens are distin-

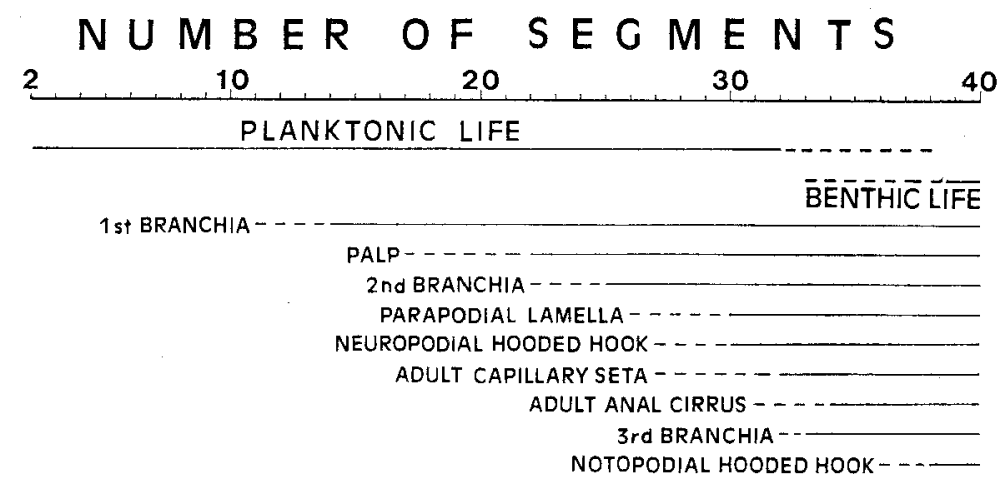

Fig. 7. Mode of life and development of adult characteristics in relation to the number of segments: continuous line shows acquirement of the characteristic in all specimens examined; broken line shows that in part of specimens examined.

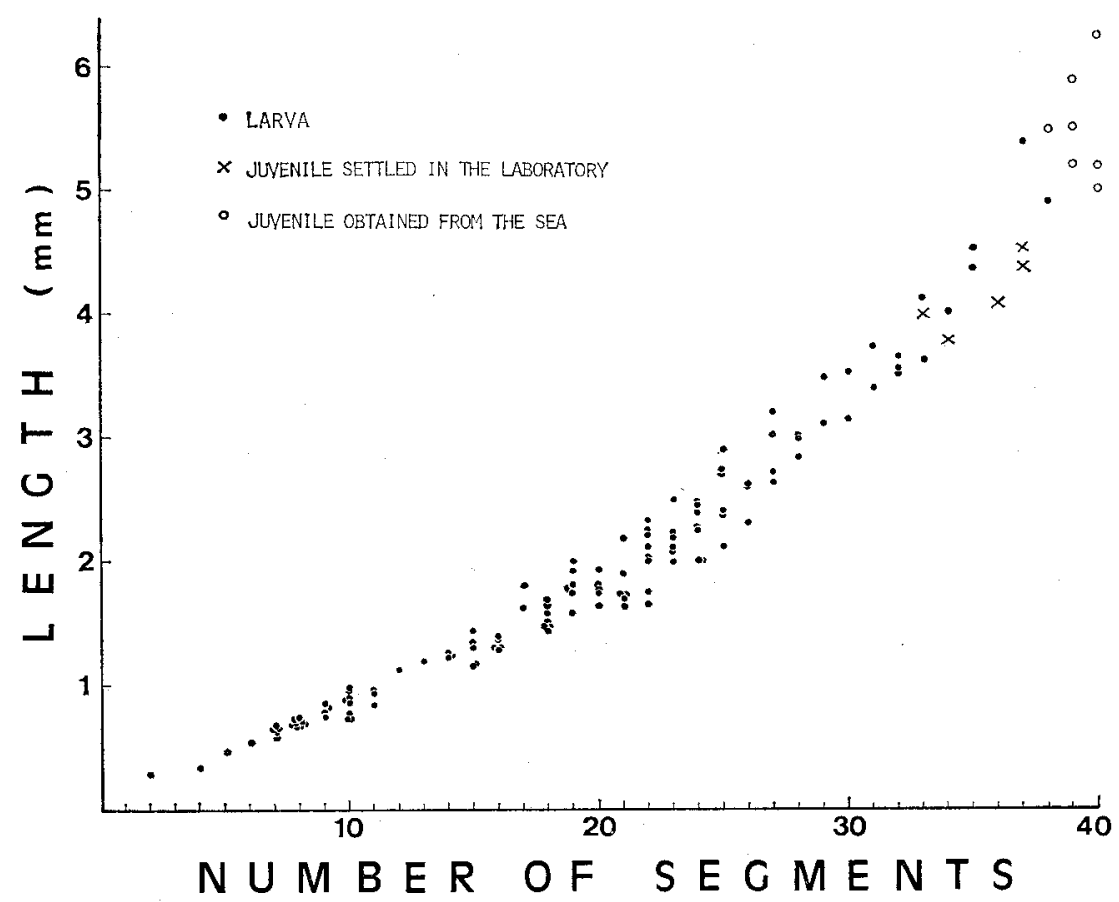

Fig. 8. Relationship between the number of segments and the body length in larva and juvenile. 
guished from the present specimens by the possession of the long larval setae in segment 2. These distinct differences between the groups of specimens from distant localities make doubtful the identity of the Peru specimens with the present specimens.

Although the culture vessel was not provided with sediments on its bottom, metamorphosed juveniles were found there while rearing the larvae. It is widely accepted that the larva postpones metamorphosis, if conditions are unsuitable for settlement (Day and Wilson, 1934; Wilson, 1955). In the present case, however, it does not seem that the larvae delayed metamorphosis in the laboratory, because the metamorphosed juveniles in the laboratory never exceeded in size those obtained from the seabed. The adverse situation, that the specimens collected from the seabed were larger than those settled in the laboratory, was the case in the present study, the reason for which had not been known. Anyway, it can be assumed that settlement occurs at the stages between the youngest juvenile of 33 segments (a length of $3800 \mu$ ) found in the culture vessel and the oldest larva of 38 segments (a length of $4850 \mu)$ or the largest larva $(5380 \mu, 37$ segments) obtained from the plankton samples (Fig. 8).

One of the most distinctive features of Paraprionospio pinnata is its large size at metamorphosis. Table 1 summarizes the numbers of segments and the lengths at

Table 1. Length and number of segments at metamorphsis and period of pelagic life in the spionid species. Specific names are followed in Pettibone (1963) (\#).

\begin{tabular}{|c|c|c|c|c|}
\hline Species & $\begin{array}{l}\text { Length } \\
(\mathrm{mm})\end{array}$ & $\begin{array}{l}\text { Number of } \\
\text { segments }\end{array}$ & $\begin{array}{l}\text { Period of } \\
\text { pelagic life }\end{array}$ & Reference \\
\hline $\begin{array}{l}\text { \# Malacoceros fuliginosus } \\
\text { (as Scolecolepis fuligionsa) }\end{array}$ & $1.062 *$ & $14^{*}$ & 34 days & Day (1934) \\
\hline $\begin{array}{r}\text { \#alacoceros tetracerus } \\
\text { (as Scolelepis ciliata) }\end{array}$ & $0.84 *$ & $12 *$ & - & Hannerz (1956) \\
\hline $\begin{array}{l}\text { \# Malacoceros vulgaris } \\
\text { (as Scolelepis girardi) }\end{array}$ & $1.08 * *$ & $12 * *$ & - & Hannerz (1956) \\
\hline Prionospio caspersi & $2.1^{*}$ & $22 *$ & - & Guérin (1970) \\
\hline Prionospio cirrifera & - & $19 *$ & - & Hannerz (1956) \\
\hline Prionospio malmgreni & $2.50^{*}$ & $25 *$ & $>1$ month? & Hannerz (1956) \\
\hline Prionospio steenstrupi & $1.4 * *-1.7 *$ & $19 * *-21 *$ & - & Hannerz (1956) \\
\hline Scolecolepides viridis & $\begin{array}{l}0.75 * * \\
(10-\text { seg. })\end{array}$ & $9 * *-13 *$ & $\begin{array}{l}24 \text { days }\left(20^{\circ} \mathrm{C}\right) \\
40 \text { days }\left(10^{\circ} \mathrm{C}\right)\end{array}$ & George (1966) \\
\hline $\begin{array}{l}\text { \# Scolelepis foliosa } \\
\text { (as Nerine foliosa) }\end{array}$ & $1.14 *$ & $15 *$ & - & Hannerz (1956) \\
\hline $\begin{array}{l}\text { \# Scolelepis squamata } \\
\text { (as Nerine cirratulus) }\end{array}$ & $\begin{array}{l}1.9 * \\
(19-\text { seg. })\end{array}$ & $19 *-30 *$ & - & Hannerz (1956) \\
\hline (as Nerine cirratulus) & - & $22 *$ & $>34$ days? & Joyner (1962) \\
\hline (as Nerinides agilis) & - & $17 *$ & - & $\begin{array}{l}\text { Dean and Hatfield } \\
(1963)\end{array}$ \\
\hline Spiophanes bombyx & $\begin{array}{l}1.9^{*} \\
(19-\text { seg. })\end{array}$ & $16 * *-19 *$ & - & Hannerz (1956) \\
\hline Spiophanes kroeyeri & $1.5 * *-2.1 *$ & $21 * *-22 *$ & - & Hannerz (1956) \\
\hline
\end{tabular}

* larva ready to metamorphose

** metamorphsed juvenile 
the time of metamorphosis in the spionid species. The listed species in this table are limited to those which have the entirely pelagic and planktotrophic type of development, because this type of development is supposed to be applied to Paraprionospio pinnata. The species listed here range in length from $0.75 \mathrm{~mm}$ to $2.50 \mathrm{~mm}$ and in the number of segments from 9 to 30, which are definitely lower than those of Paraprionospio pinnata. It is difficult to detect the relationship between the size at metamorphosis and the period of pelagic life, because the reliable data concerning the pelagic period are not sufficient. However, it can be assumed that the larger size at metamorphosis results from a higher growth rate or a longer pelagic period. Hannerz (1956) suggested that more than one month was required for the pelagic period in Prionospio malmgreni, which was closely allied to Paraprionospio pinnata. If the growth rate of this species does not exceed that of Prionospio malmgreni, the larger size attained in Paraprionospio pinnata at metamorphosis suggests that the pelagic period of Paraprionospio pinnata larva is far more than one month.

\section{Acknowledgments}

I wish to express my gratitude to Mr. I. Hayashi and Mr. M. Ueno of Kyoto University and Mr. H. Ueda of the University of Ryukyu for their kind help in collecting the samples. My hearty thanks are also due to Prof. E. Harada of the Seto Marine Biological Laboratory and Dr. M. Imajima of National Science Museum for their kindness in reading the manuscript.

\section{REFERENCES}

Berkeley, E. and C. Berkeley, 1961. Notes on Polychaeta from California to Peru. Canad. J. Zool., 39: 655-664.

1963. Neoteny in larvae of two species of Spionidae. Canad. J. Zool., 41: 149-151.

1964. Notes on some pelagic and some swarming polychaetes taken off the coarst of Peru. Canad. J. Zool., 42: 121-134.

Day, J.H. 1934. Development of Scolerolepis fuliginosa (Claparède). J. Mar. Biol. Ass. U.K., 19: 633654 .

- and D.P. Wilson. 1934. On the relation of the substratum to the metamorphosis of Scolecolepis fuliginosa (Claparède). J. Mar. Biol. Ass. U.K., 19: 655-662.

Dean, D. and P.A. Hatfield, 1963. Pelagic larvae of Nerinides agilis (Verrill). Biol. Bull., 124: 163169.

Foster, N.M. 1971. Spionidae (Polychaeta) of the Gulf of Mexico and the Caribbearn Sea. Studies on the Fauna of Curacao and other Caribbean Islands, 36 (129): 1-183.

George, J.D. 1966. Reproduction and early development of the spionid polychaete, Scolecoleprdes virides (Verrill). Biol. Bull., 130: 76-93.

Guérin, J.-P. 1970. Description des stades larvaires de Prionospio caspersi Laubier, (Annélide Polychète). Répartition des larves de Prionospin en Méditerranée occidentale. Tethys, 3: 35-40.

Hannerz, L. 1956. Larval development of the polychaete families Spionidae Sars, Disomidae Mesnil, and Poecilochaetidae n. fam. in the Gullmar Fjord (Sweden). Zool. Bidr. Uppsala, 31: 1-204.

Hayashi, I., H. Yokoyama and B. Hayashi, 1977. Benthic fauna in Kumihama Bay. Ann. Rep. Kyoto Pref. Fish. Exp. Sta. 1975: 109-123. (In Japanese).

Horikoshi M. and M. Imajima, 1976. Seasonal variations in the biomass of "smaller macrobenthos" in polluted area of Tokyo Bay. Fundamental studies on communities of Tokyo Bay with a special reference to organic pollution (ed. K. Hogetsu): 43-53. (In Japanese). 
Joh, H., Y. Hayashi and R. Miyoshi, 1969. Chemical and biological studies of water pollution in Osaka Bay. Bull. Osaka Pref. Fish. Exp. Sta., (1): 23-45. (In Japanese).

Joyner, A. 1962. Reproduction and larval life of Nerine cirratulus (Delle Chiaje) family Spionidae. Proc. Zool. Soc. London, 138: 655-666.

Kikuchi, T. 1964. Ecology and biological production of Lake Naka-umi and adjacent waters, 3. Macrobenthic communities of Lake Shinji-ko and Lake Naka-umi. Spec. Publ. Seto Mar. Biol. Lab., Ser. II, Pt. 1: 21-44.

1978. The influences of pollution to the benthic fauna of bays. In Horibe, S. (ed.), Marine Science as Environmental Science, 2, Univ. Tokyo Press: 130-147 (In Japanese).

Kitamori, R. 1969. The relation between the distribution of benthic community and water pollution in Tokyo, Osaka and Ise Bay. Mizushorigijutsu (Bull. Water Treatment Tech.), 10 (8): 15-22. (In Japanese).

Miyadi, D. 1941. Marine benthic communities of the Ise-wan and the Mikawa-wan. Mem. Imp. Mar. Obs., 7: 503-524.

Pettibone, M.H. 1963. Revision of some genera of polychaete worms of the family Spionidae, including the description of a new species of Scolelepis. Proc. biol. Soc. Wash., 76: 89-103.

Wilson, D.P. 1955. Some problems in larval ecology related to the localized distribution of bottom animals. In Buzatti-Traverso, A.A. (ed.), Perspectives in Marine Biology, 621 pp. Univ. Calif. Press, Berkeley: 87-88. 